TOMASZ RATAJCZAK* - ZIELONA GÓRA

\title{
XIX -WIECZNE MINISTRANTURY W ŚWIETLE „BIBLIOGRAFII POLSKIEJ” KAROLA ESTREICHERA I KWEREND W WYBRANYCH BIBLIOTEKACH NAUKOWYCH
}

Na podstawie Bibliografii polskiej Karola Estreichera ${ }^{1}$ - naszego podstawowego materiału źródłowego - oraz kwerend przeprowadzonych w Bibliotece Jagiellońskiej w Krakowie (dalej: BJ), Bibliotece Kórnickiej PAN (dalej: BK), Bibliotece Narodowej w Warszawie ${ }^{2}$ oraz Bibliotece Zakładu Narodowego im. Ossolińskich PAN we Wrocławiu (dalej: Ossol.) możemy stwierdzić, że w XIX w. ministrantury, czyli instruktaże służenia do mszy św., zawierające przepisy liturgiczne wraz z tekstem mszy św., wydawano przede wszystkim w zaborze austriackim. W interesującym nas okresie ośrodkiem przodującym w produkcji tego rodzaju książek religijnych były Wadowice w Galicji Zachodniej, których oficyny wydawnicze przygotowały co najmniej dziesięć edycji ministrantur. Ponadto ten typ podręczników drukowano w Bochni (sześć wydań), Krakowie i Rzeszowie (po pięć wydań), Lwowie (trzy wydania), Brodach (dwa wydania) oraz Jaśle, Kołomyi, Nowym Sączu i Tarnowie (po jednym wydaniu). Poza Galicją Zachodnią i Wschodnią ministrantury ukazywały się jeszcze na Śląsku (Biała 1860; Bielsko 1866), w Królestwie Polskim (Warszawa: 1873, 1897, 1885), na Litwie (Wilno 1855, 1860) i w guberni wołyńskiej (Żytomierz 1860). W Estreicherowskiej Bibliografii wymieniono także chicagowską drukarnię Władysława Dyniewicza, która w latach 1874 i 1880 wypuściła Ministranturę $z$ dodatkiem dwóch pieśni narodowych.

Zapewne dalsze pogłębione poszukiwania bibliograficzne umożliwiłyby odkrycie kolejnych dokumentów, które wobec braku hasła rzeczowego nie zostały

* Tomasz Ratajczak - doktor literaturoznawstwa, adiunkt w Zakładzie Literatury Dawnej, Bibliotekoznawstwa i Edytorstwa Instytutu Filologii Polskiej Uniwersytetu Zielonogórskiego.

${ }^{1}$ Bibliografia Polska, wyd. 1: część I, Stulecie XIX (1800-1880), t. 1-7, Kraków 1870-1882; część II, Stulecie XV-XIX (1455-1889), t. 3-4, Kraków 1885-1890; [część IV], Stulecie XIX (18811900), t. 1-4, Kraków 1906-1916. Bibliografia Polska XIX stulecia, wyd. 2, t. 1-17, Kraków 19592000.

${ }^{2}$ W Bibliotece Narodowej kwerenda zakończyła się niepowodzeniem. 
do tej pory odszukane. Być może udałoby się odnaleźć te, które w ogóle uniknęły rejestracji. W tym drugim przypadku w głównej mierze musielibyśmy oprzeć się na wnikliwej kwerendzie archiwalno-bibliotecznej w pozostałych instytucjach świeckich (nie pomijając zbiorów prywatnych), a zwłaszcza w archiwach i bibliotekach kościelnych. Warto byłoby również zbadać, jak często treści właściwe ministranturom zamieszczano $w$ religijnych wydawnictwach zwartych obok innych tekstów: czy to kształtujących świadomość religijną i propagujących wiedzę o religii, czy też mających charakter liturgiczny lub paraliturgiczny.

Frekwencja ministrantur i innych druków nabożnych na ziemiach polskich była uzależniona od warunków politycznych panujących w poszczególnych zaborach. Pod tym względem najbardziej sprzyjający klimat zapewniono w zaborze austriackim, ale i tu odnotować można okres zastoju - w pierwszej połowie XIX w. Zwiększenie podaży literatury religijnej w Galicji wywołała dopiero Wiosna Ludów i ogłoszona pod jej wpływem wolność słowa, a następnie zawarcie trwałego porozumienia między Stolicą Apostolską i dynastią Habsburgów, na mocy którego Kościół instytucjonalny odzyskał w roku 1850 poważną część utraconej niegdyś wolności, a wierni - niczym nie zakłócony, przynajmniej ze strony państwa - dostęp do tekstów religijnych ${ }^{3}$. Jeszcze większe swobody zapewniła autonomia.

Przed zrywem rewolucyjnym roku 1848 w Galicji wydano zaledwie pięć ministrantur. Pierwsza z nich ukazała się w roku 1827 w Bochni, w nakładzie i drukiem Antoniego Sonki. Kolejną wydano w roku 1830 nakładem i drukiem Józefa Pokornego z Wadowic. W roku 1839 lwowska drukarnia Antoniego Pillera wypuściła Ministranture czyli Sposób stużenia do Mszy świętéj, a w latach 1841 i 1845 Franciszek Skielski z Rzeszowa wydał własnym sumptem Ministranture czyli Sposób stużenia do Mszy świętéj. Kolejne instruktaże pojawiły się już po wybuchu rewolucji wiedeńskiej, a zwłaszcza po uregulowaniu stosunków państwo - Kościół i wprowadzeniu autonomii. Mowa o dwóch edycjach lwowskich (z roku 1849) i całym szeregu druków o rodowodzie: bocheńskim $(1849,1850$, $1851,1854,1867)$, brodzkim $(1875,1877)$, jasielskim (1850), kołomyjskim (1876), krakowskim $(1862,1868,1870,1884,1892)$, nowosądeckim (1879), rzeszowskim $(1857,1864,1871)$, tarnowskim $(1883)$ i wadowickim $(1870,1876$, $1877,1878,1880,1881,1883,1888,1898)$.

Na podstawie zaprezentowanego wyliczenia widać, że w porównaniu z pierwszą połową XIX stulecia jego kolejne dziesięciolecia pod względem częstotliwości wydawania ministrantur prezentują się okazale. Warto nadmienić, że wśród drukarń, które wypuściły wówczas znane nam instruktaże, były tylko zakłady świeckie - to po pierwsze; po drugie - w produkcji interesujących nas archiwaliów specjalizowały się nie tylko oficyny drugorzędne, jednoznacznie kojarzone z ówczesnym obiegiem jarmarczno-odpustowym (do takich z całą pewnością na-

${ }^{3}$ Mamy na myśli dekrety Franciszka Józefa I z roku1850: za sprawą dokumentu z 18 kwietnia zniesiono w monarchii system józefiński, zaś na mocy dokumentu z 23 kwietnia przekazano episkopatowi prawo kształcenia i wychowania księży. Zawarte wówczas porozumienie potwierdził konkordat z 18 sierpnia 1855 r. (zob. m. in. D. Olszewski, Polska kultura religijna na przetomie XIX i XX w., Warszawa 1996, s. 44-45). 
leży zaliczyć firmę Foltynów z Wadowic ${ }^{4}$ ), lecz także typografie o bardziej renomowanej pozycji (mam tu na myśli dwie drukarnie krakowskie: „W. L. Anczyca i Sp.”, stale współpracującą ze składem książek J. Gebethnera i Sp., i drukarnię „Czasu”). Należy również podkreślić, że nakładcami i inicjatorami wydania tego typu dokumentów byli zazwyczaj właściciele oficyn.

Zaledwie w jednym przypadku mamy wiarygodną informację na temat nakładu, w jakim wypuszczono daną ministranturę. W Bibliografii polskiej Estreichera odnotowano, że rzeszowską Ministranturę czyli Sposób stużenia do Mszy świętej $\mathrm{z}$ roku 1871 przygotowano $\mathrm{w}$ liczbie tysiąca egzemplarzy ${ }^{5}$. Jest bardzo prawdopodobne, że w podobnym nakładzie wydano pozostałe tytuły, tym bardziej że forma wydawnicza i jakość papieru większości z nich należały do najtańszych, co ograniczało koszty druku do minimum, a zarazem zwiększało prawdopodobieństwo, że uda się je rozprowadzić wśród większej liczby nabywców.

Prawie wszystkie znane nam ministrantury nie mają podanej nazwy autora. Jedynie w przypadku Dobrego ministranta czyli wyjaśnienia sposobu stużenia do mszy św. (Tarnów 1883) zaznaczono, że jego autorem jest osoba duchowna, która podpisała się inicjałami J. J. R., z kolei w tytulaturze Ministrantury czyli Sposobu stużenia kapłanowi przy Ofierze mszy św. (Biała 1860) podano lakonicznie, że ułożył ją dla użytku młodzieży jej ,przyjaciel”.

Odnotowane przez Estreichera lub/i odnalezione w wyniku kwerend bibliotecznych dokumenty liczyły najczęściej dwanaście stron (sześć kart) oraz miały niewielki format $\left(12^{\circ}\right.$ lub $\left.16^{\circ}\right)$. Ich cechy wydawnicze oraz zawartość treściową przybliżymy na podstawie poznanych z autopsji publikacji wadowickich: Ministrantury czyli Sposobu stużenia do Mszy świętey z roku 1830 (miejsce przechowywania: Ossolineum; syg. 10.188 I) oraz nieodnotowanego przez Estreichera, a odnalezionego w zbiorach prywatnych Ludwiki Foltin z Wadowic (dalej: LF) ${ }^{6}$ Sposobie stużenia do mszy św. z roku 1898 (dokument nieskatalogowany).

Druk z roku 1830 nie ma oprawy, bowiem opuścił drukarnię w formie sfalcowanych i związanych arkuszy (to dość powszechna w pierwszej połowie XIX w. praktyka wypuszczania broszur i książek). Jest bardzo prawdopodobne, iż równie skromny wygląd miały jego późniejsze wznowienia. Zapewne wznowienia te miały podobny układ treściowy.

Oto jak przedstawia się zawartość jednej z najstarszych ministrantur XIXwiecznych. Na jej stronie 3 (poszczególne strony odnalezionej instrukcji nie są numerowane) zamieszczono napisany w języku polskim tekst wprowadzający, w którym czytamy: „Cokolwiek jest świętem, święcie także powinno bydź sprawowane; zaczém każdy, który służbę Ministranta pełnić zamyśla, pełen uszano-

${ }^{4} \mathrm{O}$ wadowickim ośrodku książki religijnej piszę w książce Ksiqżka religijna i quasi-religijna $w$ wadowickim repertuarze wydawniczym (1825-1940), [w przygotowaniu redakcyjnym]. Zob. też T. Ratajczak, Wadowickie drukarstwo w XIX i pierwszej połowie XX w., „Roczniki Biblioteczne”, 44 (2000) s. 135-145.

${ }^{5}$ Estreicher, Bibliografia Polska, wyd. 1, cz. I, t. 3, s. 141.

${ }^{6}$ Ludwika Foltin - wdowa po Leonie Foltinie vel Foltynie, którego rodzina przez trzy pokolenia rozwijała wadowickie drukarstwo, specjalizując się w produkcji zwłaszcza różnej maści druków religijnych. 
wania do niéy przystąpi, bo oto! Ministrant trojaki na siebie bierze obowiązek: już to pomagania Kapłanowi w odprawianiu owéy bezkrwawéy Ofiary, już to odpowiadania mu imieniem zgromadzonego ludu; już to wzywania tegoż odgłosem dzwónka do szczególnéy pobożności. Będąc tak ważnym przy téy świętey ofierze sługą, czyliż nie powinien się stać, w pełnieniu swéy świętey służby Aniołów naśladować? Niechże tedy Ministrancie! twoje oczy, ręce, i cały układ ciała okażă, jak mocno dusza twoja przejęta wielkością téy ś[w]. usługi, i naydroższéy Mszy Ofiary!"

Adresatem cytowanych słów (a zarazem całej broszury) jest zatem odbiorca indywidualny, a jeszcze dokładniej - chłopiec bądź mężczyzna, który „służbę Ministranta pełnić zamyśla". Od czytelnika mającego doświadczyć egzystencjalnego spotkania z Bogiem wymaga się, aby naśladował Aniołów, aby jego odpowiedź na uobecniający się w trakcie mszy św. zbawczy czyn Chrystusa (,,świętą ofiarę") była całościowa, to znaczy wewnętrzna i zewnętrzna, angażująca wszystkie władze człowieka („Niechże [...] twoje oczy, ręce, i cały układ ciała okaża, jak mocno dusza twoja przejęta"). We wprowadzeniu tym wymienia się ponadto podstawowe „obowiązki” ministranta w czasie zgromadzenia liturgicznego. Dotyczą one posługi nie tylko kapłanowi, któremu ministrant zobowiązany jest pomagać w odprawianiu ,bezkrwawéy Ofiary”, ale także wiernym, w imieniu których odpowiada na słowa kapłana i którym podaje właściwe wezwania.

Kolejne fragmenty Ministrantury zawierają szczegółowe przedstawienie sprawowania i przebiegu czynności liturgicznych, przy czym przepisy porządkowe zapisano tu $\mathrm{w}$ języku polskim, a treści wypowiadane podczas zgromadzenia liturgicznego (np. anamnezy, aklamacje, doksologie, epiklezy, inwokacje) - zgodnie z nakazem Soboru Trydenckiego - po łacinie. Na stronie 5 zaznaczono, czym różni się zwykła msza od nabożeństwa pogrzebowego (msza pogrzebowa nie ma rozbudowanego dialogu wstępnego), zaś na dwóch ostatnich zakreślono specyfikę celebracji eucharystycznej w klasztorach oo. Dominikanów (zasadnicza różnica u Dominikanów polega na przygotowaniu darów jeszcze przed rozpoczęciem liturgii) ${ }^{7}$.

Dużo uwagi poświęca się w Ministranturze ruchowej dymensji zgromadzenia liturgicznego - postawom, gestom, czynnościom. Przytoczmy dla przykładu fragment, w którym ludzka cielesność jawi się jako miejsce uwielbienia Boga: „Przychodząc do Ołtarza, lub przechodząc przez środek jego, jeżeli tam Nayświętszy Sakrament wystawiony, lub w Cyboryium zamknięty, uklęknij; jeżeli zaś nie, głową tylko ukłon zrobi. To kilka razy podczas Mszy Ś[w.] uczynić wypadnie". (s. 3-4)

Odcięcie się od dualistycznego pojmowania człowieka jest widoczne w kolejnym z zachowanych do dziś druków o charakterze liturgicznym - Sposobie stużenia do mszy świętej z roku 1898. Ten wydany pod koniec XIX wieku instruktaż ${ }^{8}$ ma niewielką objętość (12 stron), mały format $\left(16^{\circ}\right)$ oraz jest dwujęzyczny. W odróżnieniu od poprzednio omówionej instrukcji zaopatrzono go w ilustrowaną

${ }^{7} \mathrm{O}$ wpływie poszczególnych rodzin zakonnych na liturgię wspomina B. Nadolski, Liturgika, t. 1: Liturgika fundamentalna, Poznań 1989, s. 51.

${ }^{8}$ Jego kolejne wydanie wadowickie miało miejsce w roku 1905. 
i barwioną na kolor fioletowy broszurową okładkę (zamieszczony na niej miedzioryt przedstawia ozdobiony świecami ołtarz z nastawą mieszczącą krzyż), zaś na odwrocie jego strony tytułowej uwzględniano ogólną wzmiankę „Za zezwoleniem Zwierzchności duchownej”, mającą potwierdzać zgodność proponowanych treści z nauką Kościoła. Ponadto w broszurze tej nie zamieszczono wstępu i uwag na temat różnic w sprawowaniu poszczególnych rodzajów liturgii, ale w zdecydowanie większym stopniu zadbano o czytelność wskazówek i prawidłową korektę, ułatwiając lekturę całości.

Najprawdopodobniej na XIX-wiecznych ministranturach wzorowane są instruktaże z pierwszej połowy ubiegłego stulecia - ów problem nie mieści się jednak w ramach niniejszego opracowania.

\section{WYKAZ XIX -WIECZNYCH MINISTRANTUR (uklad chronologiczno-alfabetyczny)}

1827

1. Ministrantura czyli sposób stużenia do Mszy świętéj. Bochnia: [b. nakł.], druk. A. Sonki, $12^{\circ}$, k. 6 .* $^{*}$

BJ syg. 4143337 I

1830

2. Ministrantura czyli Sposób stużenia do Mszy św. Wadowice: nakł. i druk. J. Pokornego, $16^{\circ}$, k. 6 nlb.

Ossol. syg. I 10.188

1839

3. Ministrantura czyli Sposób stużenia do Mszy świętéj z tłómacz[eniem] polsk[im]. Lwów: [b. nakł.], [druk. A. Pillera], $8^{\circ}$, [b. obj.].

\section{1}

4. Ministrantura czyli sposób służenia do Mszy świętej. Rzeszów: nakł. i druk. F. Skielskiego, $8^{\circ}$, s. 15.*

BK syg. 174342

\section{5}

5. Ministrantura czyli sposób stużenia do Mszy świętej. Rzeszów: nakł. i druk. F. Skielskiego, $8^{\circ}$, s. 15.

BJ syg. 41438 I

1849

6. Ministrantura czyli sposób stużenia do Mszy świętéj. Wydanie trzecie po- 
prawione. Bochnia: [b. nakł.], druk. W. Pisza, $12^{\circ}$, [b. obj.].

7. Ministrantura czyli sposób stużenia do Mszy świętéj. Lwów: [b. nakł.], [druk.] F. Galińskiego, $16^{\circ}$, [b. obj.].

8. Ministrantura czyli Sposób służenia do Mszy św. księżom świeckim i zakonnym. Lwów: [b. nakł.], [druk.] Jabłońskiego, 12º [b. obj.].

\section{0}

9. Ministrantura czyli sposób służenia do Mszy świętéj. Bochnia: nakł. i druk. W. Pisza, $12^{\circ}$, s. $12 .^{*}$

BJ syg. 41435 I

10. Ministrantura czyli sposób stużenia do mszy św. Jasło: nakł. i druk. A. Rusinowskiego, $16^{\circ}$, s. $12 .^{*}$

BJ syg. $41436 \mathrm{I}$

Ossol. syg. I 131.905

\section{1}

11. Ministrantura czyli sposób stużenia do Mszy świętéj oraz słowniczek polsko-łaciński. Bochnia: [b. nakł.], [druk.] W. Pisza, 12º, s. 24.

\section{4}

12. Ministrantura czyli sposób stużenia do Mszy świętéj. Wydanie czwarte poprawione. Bochnia: nakł. i druk. W. Pisza, $12^{\circ}$, [b. obj.].

\section{5}

13. Ministrant Kapłana przy Ofierze Mszy św. Wilno: nakł. R. Rafałowicza, [b. druk.], $16^{\circ}$, [b. obj.].

\section{7}

14. Ministrantura czyli sposób stużenia do Mszy świętej. Rzeszów: nakł. i druk. J. A. Pelara, $8^{\circ}$, s. 16.

\section{0}

15. Ministrantura czyli Sposób stużenia do Mszy świętéj. Wilno: nakł. księgarni J. Hussarowskiego, [b. druk.], $8^{\circ}$, s. 15.

16. Ministrantura, czyli sposób slużenia do Mszy św. Żytomierz: nakł. ksiegarni J. Hussarowskiego, [b. druk.], $12^{\circ}$, s. 12.

17. Ministrantura czyli Sposób stużenia kapłanowi przy ofierze Mszy św., dla użytku młodzieży ułożyt jéj przyjaciel. Biała: [b. nakł.], druk. E. Feitzingera, 12º, s. 22.

\section{2}

18. Ministrantura czyli sposób stużenia do Mszy świętej. Kraków: [b. nakł.], druk. F. K. Pobudkiewicza, $16^{\circ}$, s. 16.

BJ syg. 4143999 I 


\section{4}

19. Ministrantura czyli sposób stużenia do mszy św. Wydanie czwarte poprawne. Rzeszów: [b. nakł.], druk. J. A. Pelara, $12^{\circ}$, [b. obj.].

\section{6}

20. Ministrantura czyli sposób stużenia do Mszy świętej. Bielsko: nakł. i druk. R. Zawadzkiego, $12^{\circ}$, s. 12.

BJ syg. 41440 I

\section{7}

21. Ministrantura czyli sposób stużenia do mszy świętéj. Bochnia: nakł. i druk. W. Pisza, $12^{\circ}$, s. 12.

\section{8}

22. Ministrantura czyli sposób stużenia do Mszy świętej. Kraków: nakł. i druk. Jaworskiego, $16^{\circ}$, s. 16.

BJ syg. 41441 I

\section{0}

23. Ministrantura czyli Sposób stużenia do Mszy św. Wadowice: [nakł.] i druk. F. Foltyna, $16^{\circ}$, s. 12.

BJ syg. 41442 I

24. Ministrantura czyli sposób stużenia do Mszy świętej. Kraków: nakł. i druk. Jaworskiego, $16^{\circ}$, s. 16.

BJ syg. 41443 I

\section{1}

25. Ministrantura czyli sposób stużenia do Mszy świętej. Rzeszów: nakł. i druk. J. A. Pelara, $8^{\circ}$, s. 16.

\section{3}

26. Ministrantura czyli sposób stużenia do Mszy świętej z ttómaczeniem polskiem. Warszawa: [b. nakł.], [b. druk.], [b. for.], [b. obj.].

\section{4}

27. Ministrantura $z$ dodatkiem dwóch pieśni narodowych. Chicago: [b. nakł.], druk. W. Dyniewicza, [b. for.], [b. obj.].

\section{5}

28. Ministrantura czyli sposób stużenia do mszy św. Brody: nakł. i druk. I. Rosenheima, $16^{\circ}$, s. 16 .

29. Ministrantura, czyli sposób stużenia do Mszy św. Wadowice: nakł. i druk. 
F. Foltyna, $12^{\circ}$, s. 12.

BJ syg. 41444 I

30. Ministrantura czyli Sposób Stużenia do Mszy Świętej.Kołomyja: nakł. i druk.

M. Biołusa, $16^{\circ}$, s. $12 .^{*}$

Ossol. syg. $73.053 \mathrm{I}$

1877

31. Ministrantura czyli sposób stużenia do mszy św. Brody: nakł. i druk. I. Rosenheima, $16^{\circ}$, s. 16.

32. Ministrantura, czyli sposób stużenia do Mszy św. Wadowice: nakł. i druk. F. Foltyna, $12^{\circ}$, s. 12.

BJ syg. 40362 I

1878

33. Ministrantura, czyli sposób stużenia do Mszy św. Wadowice: nakł. i druk. F. Foltyna, $16^{\circ}$, s. $12 .^{*}$

BJ syg. 40362 I

1879

34. Ministrantura czyli sposób stużenia do mszy św. Nowy Sącz: nakł. i druk. J. Pisza, $16^{\circ}$, s. 15 .

BJ syg. 40363 I

\section{0}

35. Ministrantura, czyli sposób stużenia do Mszy św. Wadowice: nakł. i druk. F. Foltyna, $12^{\circ}$, s. 12.

BJ syg. $40360 \mathrm{I}$

36. Ministrantura czyli sposób stużenia do mszy św. z dodatkiem dwóch pieśni narodowych. Chicago: [b. nakł.], druk. W. Dyniewicza, [b. for.], [b. obj.].

\section{1}

37. Ministrantura czyli sposób stużenia do mszy św. Wadowice: nakł. i druk. F. Foltyna, $12^{\circ}$, s. 12.

BJ syg. 40359 I

\section{3}

38. Ministrantura [czyli sposób stużenia do mszy św.] Wadowice: [nakł. i druk. F. Foltyna], [b. for.], [b. obj.].

39. (J. J. R. z Z., ks.), Dobry ministrant czyli wyjaśnienie sposobu stużenia do mszy św. przez..., Tarnów: [b. nakł.], druk. J. Pisza, 8º, s. 22.

\section{4}

40. Ministrantura czyli sposób stużenia do mszy świętej. Wydanie nowe. Kraków: nakł. Gebethnera i Sp., druk. W. L. Anczyca i Sp., 8º, s. 12.

BJ syg. 44190 I 


\section{5}

41. Ministrantura. Warszawa**

\section{8}

42. Sposób stużenia do Mszy św. Wadowice: [b. nakł.], [druk. F. Foltyna], [b. for.], [b. obj.].

\section{2}

43. Ministrantura czyli sposób stużenia do Mszy św. Odb. z dziełka: O Mszy św. Kraków: [b. nakł.], druk. „Czasu”, 8º s. 12.*

BJ syg. 4144434

\section{7}

44. Ministrantura czyli stużenie do mszy świętej z ttumaczeniem polskim. Warszawa: [b. nakł.], druk. F. Czerwińskiego, 16º, s. 15.*

BJ syg. 78866 I

\section{8}

45. Sposób stużenia do mszy św. Wadowice: nakł. i druk. F. Foltyna, $8^{\circ}$, s. $12 *^{*}$

LF (dokument nieskatalogowany)

Pozycje pominięte w Bibliografii polskiej K. Estreichera oznaczono symbolem *

Pozycje uwzględnione jedynie w spisie chronologicznym Bibliografii polskiej K. Estreichera oznaczono symbolem ** 


\title{
ANWEISUNGEN FÜR MESSDIENER AUS DEM 19. JAHRHUNDERT IM LICHTE DER „POLNISCHEN BIBLIOGRAPHIE” VON KAROL ESTREICHER UND DER IN AUSGEWÄHLTEN WISSENSCHAFTLICHEN BIBLIOTHEKEN DURCHGEFÜHRTEN RECHERCHEN
}

\author{
Zusammenfassung
}

Dieser Artikel bildet den Versuch einer Charakteristik der sog. „Ministranturen” aus dem 19. Jahrhundert hinsichtlich ihrer verlegerischen und inhaltlichen Merkmale. Hierbei handelt es sich um Anleitungen für Messdiener, die sowohl liturgische Vorschriften als auch den Text der Heiligen Messe enthielten. Diese Dokumente werden vor allem im Lichte der „Polnischen Bibliographie” von Karol Estreicher sowie der in der Jagiellonischen Bibliothek in Krakau, der Kórnik-Bibliothek der Polnischen Akademie der Wissenschaften, der Nationalbibliothek in Warschau und der Bibliothek des Ossoliński-Nationalinstituts der Polnischen Akademie der Wissenschaften in Wrocław (Breslau) durchgeführten Recherchen aufgezeigt. Die Analyse des zusammengetragenen Quellenmaterials bestätigt, dass das ganze 19. Jahrhundert hindurch mindestens 44 Lehrbücher dieser Art erschienen sind, davon 35 im ehemaligen österreichischen Teilungsgebiet. Bis heute sind 23 solcher Anweisungen für Ministranten erhalten geblieben (die meisten von ihnen befinden sich in den Beständen der Jagiellonischen Bibliothek), unter denen sich auch 9 von Estreicher nicht erwähnte Titel befinden.

Aus dem Polnischen übersetzt von Herbert Ulrich 